South African Income Tax Implications For Income Earned In Virtual Worlds

S J Pienaar; T L Steyn

Journal of Applied Business Research; Mar/Apr 2010; 26, 2; ABI/INFORM Global pg. 47

\title{
South African Income Tax Implications For Income Earned In Virtual Worlds
}

\author{
SJ Pienaar, University of Pretoria, South Africa
}

TL Steyn, University of Pretoria, South Africa

\begin{abstract}
There has been a significant increase in the number of internet business and e-commerce transactions over the last few years. More recently, the development of virtual worlds on the internet has become an important feature of the business environment. Although some research has been conducted in the United States of America into the tax consequences of income earned in virtual worlds, no such research has been conducted in South Africa. This study adds to the American research by providing a critical analysis of the topic from the South African tax perspective. The specific aim of the study was to determine whether income earned by South African residents from structured and unstructured virtual worlds respectively would qualify as gross income in terms of the South African Income Tax Act 58 of 1962. It builds on previous international research, but offers a new perspective from the South African point of view. The study will make a valuable theoretical contribution to the application of the basic principles of gross income, and will deal with a brand new concept which did not exist when the principles were laid down. The research was limited to determining whether the income earned in virtual worlds by South African residents who are taxed on their world-wide income would be included in gross income as defined by the South African Income Tax Act. Capital gains tax consequences were not considered in any transaction where the income was classified as being of a capital nature. Also excluded were deductions available to taxpayers in terms of the income included in gross income, and there is no detailed discussion on when a taxpayer would be regarded as engaging in virtual worlds as a hobby as opposed to conducting a business. Future research could be extended to this particular area. This research concluded that most transactions in virtual worlds resulting in income would qualify as gross income under the South African Income Tax Act. At this stage, the only possible disqualification in terms of the South African gross income definition appears to be income received "of a capital nature".
\end{abstract}

Keywords: Virtual worlds; structured virtual worlds; unstructured virtual worlds; South African resident; gross income

\section{INTRODUCTION AND BACKGROUND}

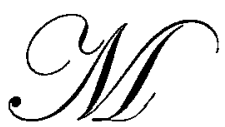

ilton Friedman (2008), a winner of the Nobel Prize for Economics, once said that the most important way in which the internet would affect the big issue was that it would make it more difficult for government to collect taxes. This statement is valid as far as income earned through formal business activities on the internet are concerned, but it is even more applicable to the recent development of virtual worlds on the internet.

Lymer (2003:249), referring to the significant effect of the internet on businesses, correctly noted that this was but the start of a revolution. The taxation of so-called e-commerce transactions has been suggested as a field for tax research, as it is of increasing prominence in the current business environment. The existing tax systems were designed to operate in physical environments, and research supporting the development of systems addressing ecommerce transactions is still very limited. As surmised, the initial e-commerce transactions were only the tip of the iceberg and the latest internet developments are beginning to attract the attention of real-world authorities (Pasick, 2006). Deloitte (2007) confirmed the reason for the real-world tax authorities' interest in virtual economies, which is that real people are spending real money on entirely virtual goods and services. 
Users of virtual worlds like Second Life and World of Warcraft (WoW) transact millions of dollars-worth of virtual goods and services every day (Pasick, 2006). Furthermore, according to Au (2008:9), Second Life has its own currency: the Linden dollar (L\$). Linden dollars are exchangeable for real-life dollars. Figure 1 provides a summary of the value of user to user transactions from January 2005 to August 2008.

For the purposes of this study, virtual worlds are defined as: “...role-playing games taking advantage of the internet's ability to create graphic representations of reality also known as Massively Multiplayer Online RolePlaying Games (MMORPGs). Role-playing games fall along a continuum ranging from highly-structured games to highly-unstructured games" (Camp, 2007).

Figure 1: Value of User-to-User Transactions in Second Life

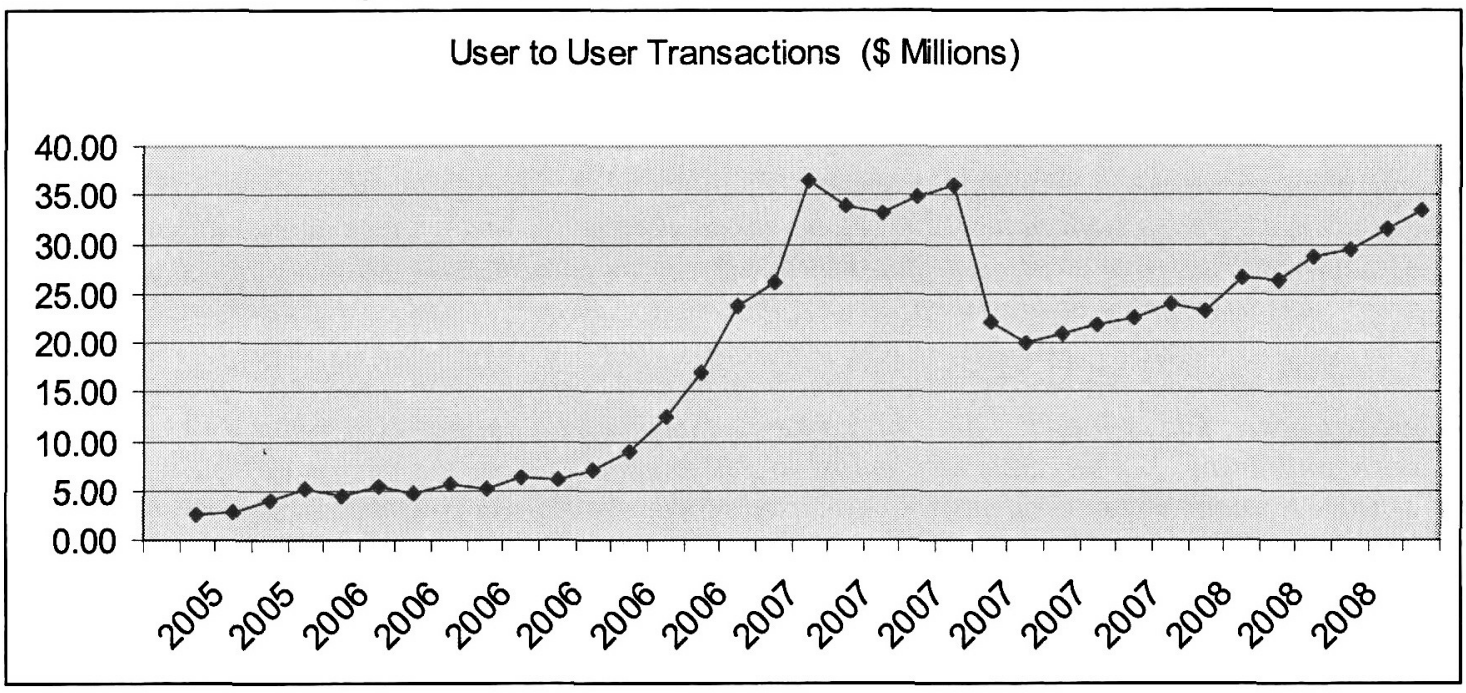

Linden Lab (2008)

The increase in value of user to user transactions corresponds with the growing number of active Second Life residents online as well as the total number of residents, as shown in Figure 2.

From August 2006, the total number of residents in Second Life increased from an average of 500000 to over 4000000 residents in mid-2007. For the same period, the average number of users online "living" concurrently in this environment increased from just below 5000 to 25000 .

The active subscriptions in WoW, as indicated in Figure 3, and the total estimated subscriptions to all Massively Multiplayer Online Games (MMOG), as indicated in Figure 4, correspond with the steady incline displayed by the Second Life graphs. The total number of active subscriptions to WoW, which was launched in October 2004, had increased to approximately 5000000 subscribers by the beginning of 2006, reaching 10000000 in January 2008. Total MMOG active subscription statistics starting in 1998 inclined to around 6000000 subscribers in 2006, showing approximately 16000000 active subscribers at the beginning of 2008 .

Considering that an estimated 16 million registered accounts had been activated in all MMOGs by March 2008 (Woodcock, 2008), this might suggest an important development to be investigated by tax authorities in the near future. These statistics and the fact that users are willing to pay real money to obtain assets in these virtual worlds mean that a real income is being earned from virtual transactions. 
Figure 2: Concurrent Residents Online and Total Residents

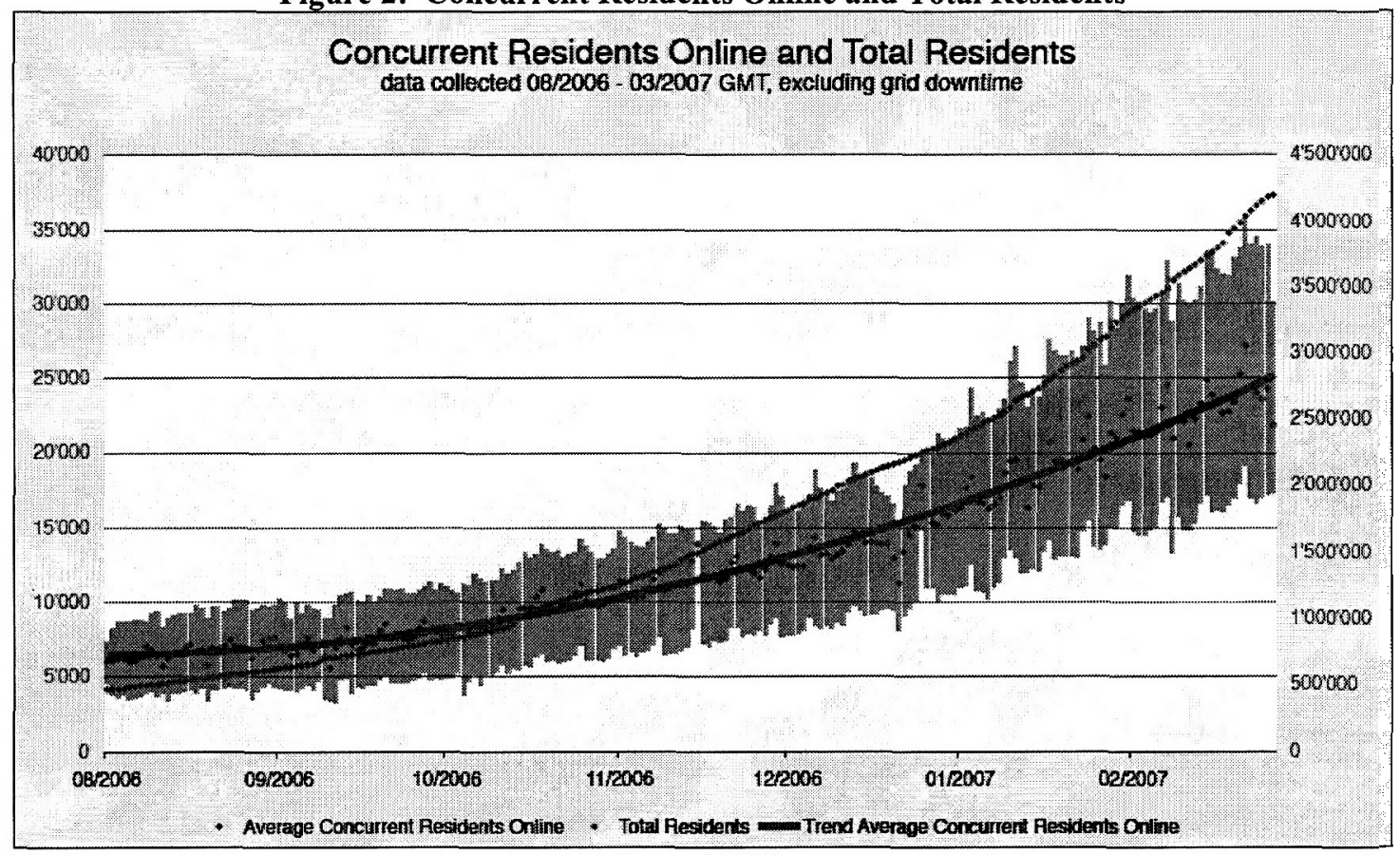

Lang (2007)

Figure 3: MMOG Active Subscriptions - World of Warcraft

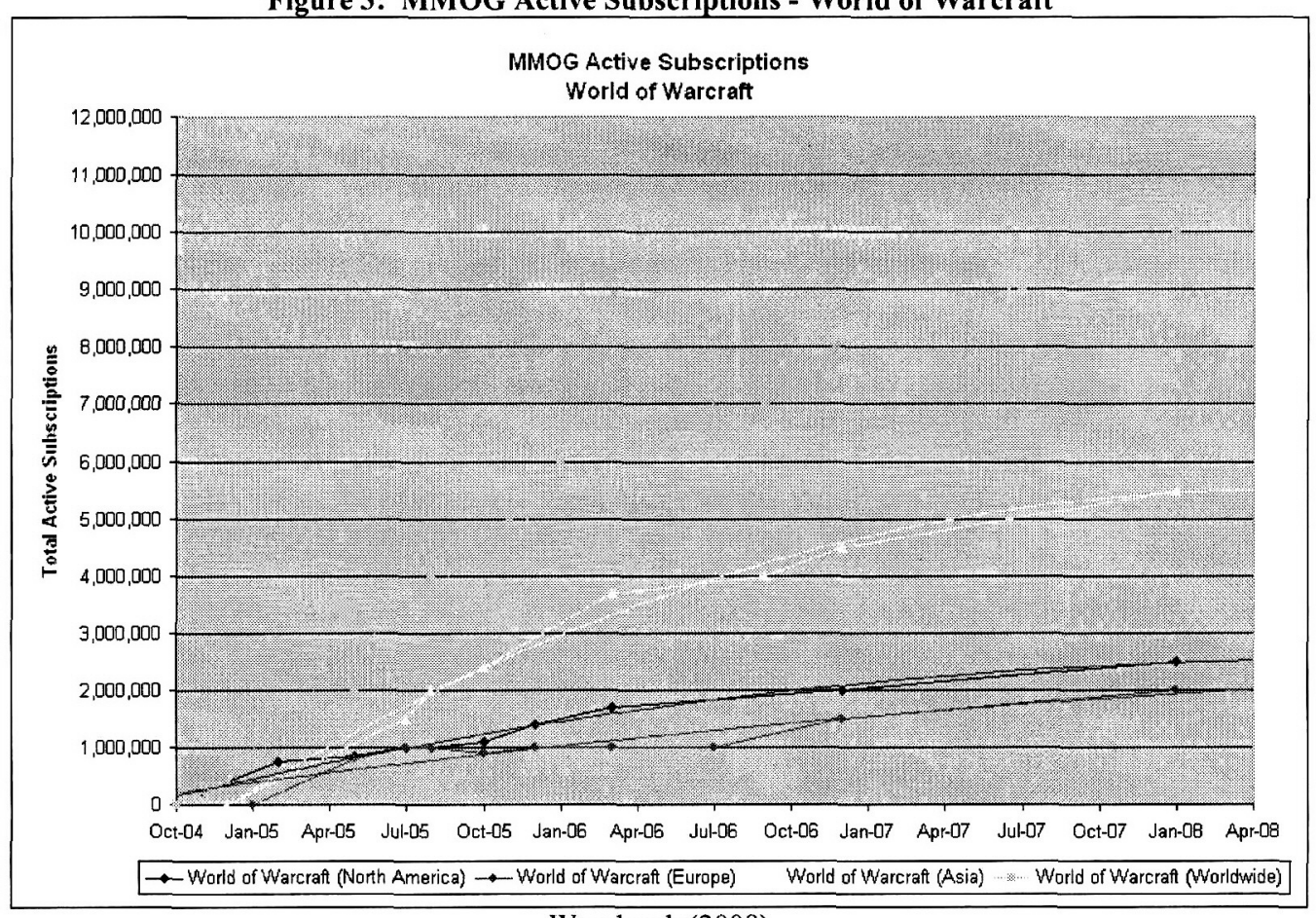

Woodcock (2008) 
Figure 4: Total MMOG Active Subscriptions

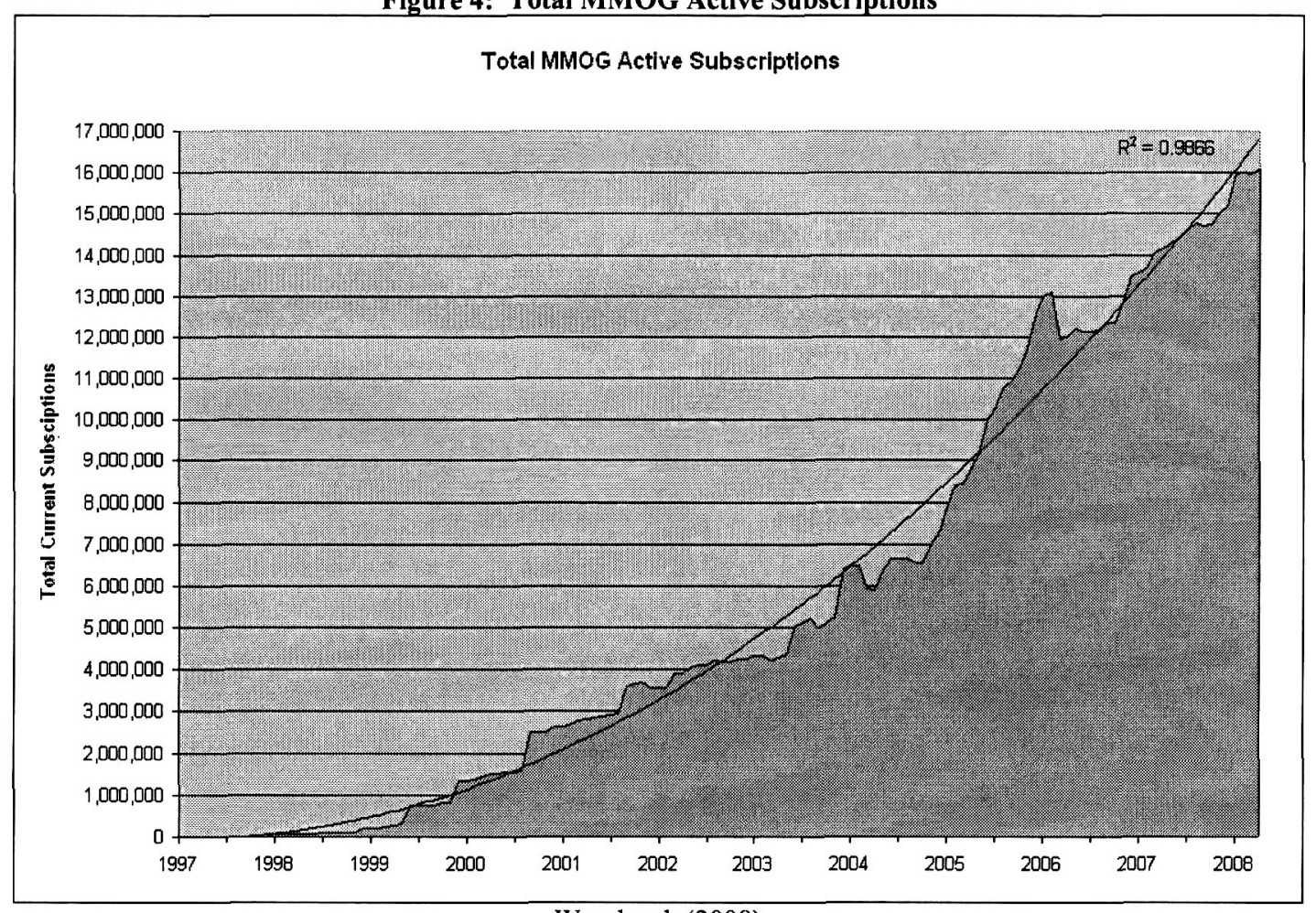

Woodcock (2008)

An extensive search of leading electronic journal databases suggests that no academic research has as yet examined whether income earned in virtual worlds would qualify under the gross income definition as defined in the South African Income Tax Act 58 of 1962 (the South African Income Tax Act). While Bray (2007:22) emphasises the new multi-disciplinary research opportunities created by virtual worlds, His comment has initiated very little research. The play's the thing: A theory of taxing virtual worlds (Camp, 2007) and 'Stranger than fiction': Taxing virtual worlds (Lederman, 2007) present international research on the taxation of income earned in virtual worlds.

There is currently no reliable way of determining the extent to which qualifying gross income is earned from virtual worlds by South African residents. However, Mr Pravin Gordhan, Commissioner of the South African Revenue Service (SARS), said in 2000 that the detection of tax evasion by means of Internet transactions would be one of SARS' primary tasks. He further noted that SARS was fortunate in that many evasion schemes would start in the developed world and would filter into South Africa only about six months to a year later, by which time SARS would be adequately prepared for dealing with the problem. The Joint Economic Committee in the United States of America indicated that they were in the preliminary stages of investigating the issues, including what kind of public policy questions virtual economies raised pertaining, inter alia, to taxes (Arrison, 2007). Given Mr Gordhan's statement, it should not be long before SARS shows increased interest in such transactions and determines which of them should form part of a resident's taxable income.

This research would therefore be helpful to both the taxpayer and SARS in identifying possible lacunae in South African legislation in respect of virtual income qualifying as gross income. The study is further significant in its attempts to look at very basic principles in South African tax legislation from a new perspective.

The country of focus for this study is South Africa. Previous research addressing the taxability of income earned in virtual worlds conducted by B.T. Camp (2007) and L. Lederman (2007) will be replicated in the South African context. South African case law determining whether a transaction is of an income or capital nature will be analysed and the principles found there applied to determine whether income from virtual worlds would qualify as gross income as defined in the South African Income Tax Act. 
In terms of section 5(1) of the South African Income Tax Act, income tax is paid on the taxable income received by a person or accrued to a person during the year of assessment. Taxable income is defined in section 1 of the South African Income Tax Act as the amount remaining after the deduction of any allowable expenditure and/or any set-offs against the income of the taxpayer. Section (1) of the South African Income Tax Act furthermore defines the term as:

...the amount remaining of the gross income of any person for any year or period of assessment after deducting there from any amounts exempt from normal tax under Part I of Chapter II.

From the above definition of income, it is evident that the definition of gross income is vital to calculating the taxable income of a taxpayer. Section 1 of the South African Income Tax Act defines gross income as follows:

“...in relation to any year of assessment, [gross income] means-

1. in the case of any resident, the total amount, in cash or otherwise, received by or accrued to or in favour of such resident; or

2. in the case of any person other than a resident, the total amount, in cash or otherwise, received by or accrued to or in favour of such person from a source within or deemed to be within the Republic, during such year of period of assessment, excluding receipts or accruals of a capital nature... ".

3. A South African resident, for the purposes of this study, is defined: "...in relation to a natural person as either a person ordinarily resident in South Africa or a person who meets the requirements of the physical presence test" (paragraph (a) of the definition of "resident" in section 1 of the South African Income Tax Act).

According to the above-mentioned definition of gross income, the important element to be investigated in this study is whether the income is of a capital or revenue nature. If the income is of a revenue nature it is included in the taxpayer's gross income. Several South African cases deal with revenue nature versus capital nature of receipt and accruals. This is because the term "capital" is not defined in the South African Income Tax Act (Clegg \& Stretch, 2008:\$5.1). It follows therefore that, if an income is of a capital nature, the amount will not be included in a taxpayer's gross income. Even though capital gains are specifically excluded from the gross income definition as stated in the South African Income Tax Act, a portion of the capital gain, subject to certain exceptions, is included in the taxable income of a taxpayer in terms of section 26A of the South African Income Tax Act.

\section{OBJECTIVE, RESEARCH DESIGN AND METHODOLOGY}

The main purpose of this study is to determine the income tax consequences for income earned in virtual worlds and, more specifically, whether such income would qualify as gross income in terms of the definition in section 1 of the South African Income Tax Act.

The study will be guided by the following specific research objectives:

- $\quad$ To determine whether the income earned by South African residents from structured virtual worlds would qualify as gross income as defined in the South African Income Tax Act.

- $\quad$ To determine whether income earned by South African residents from unstructured virtual worlds would qualify as gross income as defined in the South African Income Tax Act.

As the South African income tax system is one of residence, it means that world-wide receipts derived by a resident (as defined in section 1 of the South African Income Tax Act) are included in the resident's gross income (Jordaan, Koekemoer, Stiglingh, Van Schalkwyk, Wasserman \& Wilcocks, 2008: 41). Non-residents (persons who are not residents as defined by the South African Income Tax Act) pay income tax only on receipts derived or deemed to be derived from a source within South Africa (with certain exceptions). Non-residents are therefore taxed on a source-based system of tax. This study will focus solely on income earned from virtual worlds by residents as defined by the South African Income Tax Act. 
A theoretical case study will be used to determine whether income earned in structured and unstructured virtual worlds would qualify as gross income in accordance with the definition in section 1 of the South African Income Tax Act. The research conducted by Lederman (2007) and Camp (2007) will be replicated in the South African context, and South African legislation and case law will be used to determine the outcome of the study.

\section{IMPORTANCE AND BENEFITS OF THE STUDY}

From a theoretical perspective, the proposed study will make a valuable contribution vis à vis the application of basic principles. However, it will consider a brand new concept, which did not exist when the principles were initially laid down, and will possibly force revenue authorities and taxpayers to look at virtual transactions more carefully. The significance of this research resides in the fact that, as far as could be determined, this is the first study to determine whether income earned from virtual worlds would qualify as gross income as defined in the South African Income Tax Act.

From a practical perspective, the findings could assist the South African Revenue Services in identifying gaps in the South African income tax legislation. Further, it could possibly assist South African taxpayers in identifying the same gaps on order to plan their income tax responsibilities.

\section{LIMITATIONS TO THE STUDY}

It must be noted that the study has been conducted within the following limitations:

1. The study will consider only income earned from virtual worlds by South African residents who are taxed on their worldwide income.

2. The study will consider only whether income earned from virtual worlds would qualify as gross income.

3. The study will not consider the capital gains tax consequences of income earned from virtual worlds.

4. The study will not consider the detailed circumstances causing a taxpayer's actions within a virtual world to be considered a business rather than a hobby.

5. The study will not consider what exclusions or deductions might be available to taxpayers, either those who constitute a trade or business or those engaging in the activity as a hobby or leisure activity.

6. The study will not consider the effect of any double taxation agreements or any other international tax rules.

\section{INCOME EARNED FROM STRUCTURED VIRTUAL WORLDS}

This study has been undertaken using US tax legislation in comparison with South African tax legislation as the basis for completed research. US tax legislation rests on the principle that all income qualifies as gross income unless it qualifies for one of three available exceptions. The South African Income Tax Act, on the other hand, states that, even if income qualified as gross income according to the required definition and this income was of a capital nature, then the income would not qualify as gross income. According to South African income tax legislation, two taxpayers could earn the same income, but one could be taxed on it and the other not, according to the rules of revenue versus capital in nature.

The South African Income Tax Act does not define "receipts and accruals of a capital nature". However, several tests are used and acknowledged in South African case law to determine whether a particular income is of a capital or revenue nature, the most important test used by the courts being that of intention (Jordaan et al., 2008: 21). The taxpayer's intention should be determined on acquisition of the asset. Generally the income would be of a revenue nature if the intention had been to sell the asset for a profit. On the other hand, it would be considered capital in nature if it had been acquired for producing income rather than for purposes of profit. For example, if a house which had been bought to earn rental income was sold, the income would be of a capital nature. It is also possible for the owner of a certain asset to change their intention during the period of ownership or to change their intention at the time of disposal (Lace Proprietary Mines Ltd v CIR (AD 1938) (9 SATC 349)). 


\section{UNDERSTANDING STRUCTURED VIRTUAL WORLDS}

Dan Miller, a senior economist for the Joint Economic Committee in the United States once said:

To me it seems unbelievable that somebody could incur some tax liability just from playing a game. The more the virtual world is purely just a gaming or entertainment function, the harder it will be to introduce taxes to it, the more it seems to be parallel to the real world, the easier it will be to introduce taxes to it (Datastream, 2007:11).

Miller's words probably reflect most people's feelings on the accumulation of assets within a virtual world which is merely a "game", as long as the assets are not cashed out for real funds (Lederman, 2007:1624). But does this feeling necessarily reflect reality? To answer this, we have first to understand something of the working of structured virtual worlds.

For the purposes of this study, structured worlds are defined as: “. ..environments where users are provided with structured adventures involving quests, raids and fights against opposing forces. Examples of such structured worlds are City of Heroes, Everquest and World of Warcraft (WoW)" (Lederman: 2007). According to Camp (2007:3), a player uses an online persona, an avatar, to assume a role within the context of the game environment of an MMORPG. According to Bartle (2004:30), people participate in virtual worlds for entertainment, social value and the experience of a "hero's journey". With reference specifically to structured worlds, the games define pre-set roles, challenges and objectives. When playing the game, a player agrees to "live" according to a set of rules and regulations in return for the benefits of playing the game (Bartle, 2004:23). These rules regulate interaction between both the player-generated avatars and the non-player characters (NPCs), all of which are provided with the game environment by the game owner (Camp, 2007:3). One of the biggest MMORPGs, WoW, describes itself as follows:

World of Warcraft is an online experience. Players assume the roles of Warcraft heroes as they explore, adventure, and quest across $a$ vast world. Whether adventuring together or fighting against each other in epic battles, players will form friendships, forge alliances, and compete with enemies for power and glory.

(World of Warcraft: 2008)

According to Camp (2007:3-4), structured games typically have three prominent characteristics:

First, each avatar fits into a strong pre-defined role which suits the overall context of the storyline. This means that each role has strengths and weaknesses which cannot be changed, as the game is pre-programmed in that particular way. The different roles support each other in various quests, treasure hunts, rescuing NPCs or any other experiences determined and provided by game owner, who rewards players for each successful experience. In structured worlds, game owners use NPCs largely to guide game play.

Secondly, players are allowed to craft but not create. In a structured game, players acquire assets by way of a treasure hunt or by completing a quest. Alternatively, players can gather or buy ingredients from other players and assemble a particular asset as defined by a recipe provided by the game owner. For example, a sword could be made by clicking on the number of ingredients prescribed by the recipe. This process is called "crafting".

Thirdly, the game consists of a number of levels. The more a player kills, the better $\mathrm{s} / \mathrm{he}$ gets at it and the avatar is automatically assigned to a higher level which will provide better odds of success to the player in a battle. The higher the level of play, the more skill is required to perform activities within the game.

According to Lederman (2007:1643), one distinctive problem, especially in scripted worlds, is the taxation of "loot drops" or prizes. Loot is obtained following the defeat of a monster, the completion of a quest or a successful treasure hunt. There are two possible ways of conceptualising loot drops: either they are property or they are not. The property rights of participants in virtual worlds are outside the scope of this study, so the provisions in agreements between game owners and players which deny players any rights in virtual property will be accepted without challenge in this study. Even though loot drops are not actual trade within a structured virtual world, it gives rise to the items players do trade with and it will influence a player's level within the game as well as the market for a certain skill in undertaking quests. 
Co-operation between players is a very important aspect of game play. To perform some of the game world's experiences, "guilds" of as many as 25 members have to be formed. Players use the pre-defined strengths of the different players to enhance the power of the guild generally. To facilitate this, players of the different professions sell or trade items with each other to craft the necessary items defined above (Camp, 2007:5). It is these exchanges which result in the game world's economy and give rise to possible tax issues.

\section{REASON FOR TRADE IN STRUCTURED VIRTUAL WORLD ITEMS}

Even though virtual world designers ban the trade of game world items (Bartle, 2004:41), and the sale of virtual game goods has been banned by certain internet auction sites (Guardian.co.uk Games Blog, 2007), this does not prevent players from trading assets from structured virtual worlds. Players with little time and a lot of money buy items in structured virtual worlds and players with more time and less money sell their items to players with money (Lederman, 2007: 1628-1629). In this way, a low-level avatar can advance to a much higher level very quickly. According to Bartle (2004: 39-40), people also buy complete online characters or assets as an investment, which also increases their status. The game owners themselves create an economy within the game world, as their recipes require a certain number of ingredients to craft an item required for a certain quest (Camp, 2007:8-9). Apart from player-to-player trade, a player might also be required to trade with NPCs for certain scarce items in the game. Game owners create this market and programme NPCs to automatically sell high and buy low.

In WoW, trade can take place by means of either exchanging two in-world items or using in-world currency to buy a certain in-world item from another player. The in-world currency used in WoW is called Gold, and can be broken down into subunits called Silver and Copper. The most common virtual item to be purchased in-world is currency. WoW Gold appears to trade around a surprising four to ten units per one US dollar. Where there is a realworld value, real-world trade starts.

\section{DOES TRADE IN STRUCTURED VIRTUAL WORLDS RESULT IN REAL MONEY TRADE?}

According to Lederman (2007:1622), people pay to participate in virtual worlds. Part of the "return" for the monthly fee paid by players is periodic "allowances" in in-world currency by the game owner to the player. However, this allowance does not permit a player to participate at a higher level of the game (Camp, 2007:11). Camp explains that real-money trade speeds up the game's progress, as it is often a great deal faster to buy a certain in-world item like a sword on an auction website as opposed to an in-world transaction, because the in-world transaction costs are considerably higher than those in real-money trade. Even though a transaction takes place in real money trade, the transaction is almost always a two-step process, because it has to be finalised in the game environment. Because the item has been paid for with real money, the in-world transaction takes place at no cost.

Apart from virtual currency and item sales, certain players sell their complete player account. A player account can consist of single or multiple avatars (Camp, 2007:12), and such accounts are valued according to the level of the characters being sold and the accompanying items they own.

According to Lederman (2007:1623), it seems obvious that individual players selling their virtual property to make a living should be taxed on their earnings, even players who sell only the occasional valuable item. However, the main debate seems to focus on whether someone should be taxed if they accumulate items or currency in the virtual world and whether in-world trade transactions would attract tax consequences. Camp's (2007:2) opinion is that "where the play ceases, taxation begins".

\section{A CRITICAL ANALYSIS FROM A SOUTH AFRICAN TAX PERSPECTIVE}

This section considers the completed research of Leandra Lederman (2007) and Brian Camp (2007) relating to the taxation of income earned in structured virtual worlds. Both studies were based on gross income as defined in $\$ 61$ of the Federal Income Tax Code of the United States of America. Section 1 of the Federal Income Tax Code of the US imposes income tax on taxable income which equates to gross income minus deductions as per $\S 63$. Gross income is defined by $\S 61$ as "all income from whatever source derived". According to US case law, income means "any undeniable accessions to wealth, clearly realised, and over which the taxpayer has complete dominion". Clearly it is not the form of income but rather the access to it that is important. 
In terms of this background the outcomes of the completed studies are compared and a critical analysis from the South African perspective is discussed.

\section{Loot (Prize) Drops}

Many virtual world participants never sell any of their in-world items. But tax problems could arise for even these players, as all the swords and gold pieces they own in a structured virtual world still hold economic value from the moment their online avatar takes ownership of the items (Lederman, 2007:1641). If these loot drops or prizes were to qualify as gross income, the receipts would be taxable, even if their owners had never physically traded with these virtual items inside the virtual world or with real money.

According to Camp (2007:14), the Supreme Court aimed to extend the reach of the gross income definition per $\S 61$ as far as was constitutionally possible. When it comes to loot drops, Revenue Services in the US look at income earned in structured virtual worlds and see taxpayers playing for prizes and awards (Camp, 2007:46). Owing to the far-reaching definition of gross income, prizes and awards are included in a US resident's gross income and, ultimately, their taxable income. However, three exceptions are expressed in statutes and cases and are interpreted in administrative guidance as what taxpayers must include in gross income. These limits are "priceless", meaning income for which there is no ascertainable fair market value, or "unrealised" income derived from the appreciation of property and "imputed" income, which arises from self-benefiting activity or property ownership (Camp, 2007:25). For income to qualify as "priceless", it should not have a readily ascertainable fair market value. If an objective market value cannot be determined to a value in US currency, there is no reportable income. The US Treasury Regulation 1.74-1(a)(2) further states that prizes and rewards be reported as income at its fair market value.

A taxpayer does not qualify for the priceless exception, as it is easy to convert a virtual item into US currency by selling it on an internet auction site. It could also be sold in-world for the in-world currency (for instance Gold in WoW), which could then be converted to US dollars. The virtual items therefore would have a readily ascertainable fair market value and would not qualify under the priceless exception (Camp, 2007:47).

South African taxpayers face a lesser risk when it comes to the classification of loot drops as awards and prizes. If a prize or lottery depends on good fortune and the transaction is not of a business nature, the transaction is consequently of a capital nature for South African income tax purposes and does not qualify as gross income (Hamel, Stiglingh \& Venter, 2008:43).

One section of the South African gross income definition determines that the amount to be included in gross income should be "the total amount in cash or otherwise" (section 1(i)). This principle correlates with the US "priceless" exception. According to South African tax legislation, there has to be an amount received or accrued if gross income is to be recognised (Hamel et al., 2008:29). In W.H. Lategan v Commissioner for Inland Revenue (1926 CPD 203), (SATC 16), it was stated that, even without the words "whether in cash or otherwise", by virtue of the word "amount" in the gross income definition, not only money but every form of property, whether corporeal or incorporeal, which has a monetary value is included in the gross income definition. This was confirmed in CIR $v$ Delfos (1933 AD 242) (6 SATC 92), when Judge Wessels said: "The tax is to be assessed on all receipts or accruals having a monetary value. If it is something which is not money's worth or cannot be turned into money, it is not to be regarded as income".

South African legislation therefore determines that, if an asset or service is received in stead of cash, the value of the asset or service should be included in gross income (Hamel et al., 2008:29). Clegg and Stretch (2008: $\$ 4.11)$ confirm that the courts have attached a very broad meaning to the word "otherwise". As long as whatever has been received can be converted into money, it can be of any nature. The fact that it may be difficult to determine the monetary value of the thing or right of action is immaterial. As long as it is has an ascertainable value, the thing or right of action is to be included in gross income. The value to be placed on an asset received instead of cash received or accruing as income is the fair market value of the asset if it was sold under fair and reasonable circumstances (Clegg \& Stretch, 2008:\$2.13). 
In CIR v Butcher Bros (Pty) Ltd (1945 AD 301) (13 SATC 21) the principle was laid down that the responsibility for proving an ascertainable money value was the Commissioner's (Hamel et al., 2008:30). Once the Commissioner had determined the amount, it became the taxpayer's responsibility to prove another. Both ITC 932 (1965 24 SATC 341) and Lace Proprietary Mines Ltd v CIR (AD 1938) (9 SATC 349) confirmed that the value of the income should be determined by valuing the asset, and that this value was normally the market value at which the asset had originally been acquired (Hamel et al., 2008:29).

The only further requirement for determining the amount of income when it is otherwise than cash is that the value should be an objective one (Ochberg v CIR (1931 AD 215) (5 SATC 93)) and CIR v Butcher Bros (Pty) Ltd (1945 AD 301) (13 SATC 21)). The value of the determined income to the taxpayer is irrelevant, since the value taken into account for gross income purposes should be determined objectively.

The market value of a loot drop can easily be determined in a number of ways. Loot can be sold to an NPC or another player in-world for in-world currency and the in-world currency can be converted to US dollars and then to South African rand. The South African Income Tax Act even specifies a method of translation from foreign currency amounts, rendering it even easier to convert the item's value to South African currency (section 25D of the South African Income Tax Act). Another indirect way of valuing the loot is to determine the average price for a similar item displayed on the many internet auction sites. Loot has a readily ascertainable fair market value, so it qualifies as gross income per the definition in the South African Income Tax Act.

According to US legislation (Camp, 2007:28-38), income from a service is realised when a taxpayer receives cash, property or services in exchange for past, present or future services by the taxpayer. Conversely, income from property can be generated in one of two ways. Simply owning a piece of property might generate income. For example, shares might generate dividends and a house might create rental income. It could also produce income if the property was sold, exchanged or otherwise disposed of. In all of the above transactions, the income has to be realised before it can be included in gross income. For income to qualify as "unrealised" means that access to it should not have been realised.

Camp (2007:47) maintains that there is a strong argument that no wealth is realised from a loot drop, as no actual cash, property or service has been received. This is because a taxpayer's ability to convert the loot to usable wealth is remote and dependant on factors beyond his control. With this exception, the fewer rights a taxpayer has to a virtual item, the better the chances are that the income will qualify as the exception. But Camp doubts whether this argument would be strong enough to save a taxpayer from paying taxes on the loot.

A requirement of the South African gross income definition is that the income should be received by or accrued to the taxpayer (section 1 of the South African Income Tax Act). This concurs to a certain extent with the realisation exception in US legislation. Income should be either a receipt or an accrual if it is to qualify as gross income. In SARS v Cape Consumers (Pty) Ltd (1999 (4) SA 1213) (61 SATC 91), it was said that there would be no receipt or accrual if a person had not received an amount or it had not accrued to him for his own benefit. As the terms "received by" or "accrued to" have not been defined in the Act, it is important to determine the exact meaning of these words by citing relevant cases.

In Geldenhuys v CIR (1947 3 SA 256) (C) (14 SATC 419), the court determined that "received by" meant that a taxpayer must have received an amount for his own benefit and on his own behalf. It is therefore clear that one person cannot be liable for income tax on an amount received on behalf of another person. However, it is irrelevant whether the taxpayer has already benefited from the transaction (Ochberg $v$ CIR 5 (1931 AD 215) (5 SATC 93)) before an amount can be included in gross income.

Regarding "accrued to", the courts tested the principle but finally decided that the most appropriate interpretation would be that income has accrued to a taxpayer when they become entitled to claim payment (Jordaan et al., 2008:14). This opinion was originally held in W.H. Lategan v Commissioner for Inland Revenue (1926 CPD 203), (SATC 16) and was confirmed in CIR v People's Stores (Walvis Bay) (Pty) Ltd (1990 (2) SA 353 A) (52 SATC 9). 
It is important to note that a taxpayer can be taxed only on receipt or accrual of the transaction (Jordaan $e t$ $a l: 2008: 15)$. Therefore, if the taxpayer is taxed when the loot drop is received, it cannot be taxed again when the loot is sold.

Considering South African tax legislation, there appears to be no reason why loot drops would not be considered as non-monetary accruals to the South African taxpayer. A taxpayer's game account would be credited with the loot as soon as a quest or raid had been completed. The virtual item could either be used for the player's own benefit until he decided to transfer the item and whatever powers were attached to another player or sold to an NPC. The loot could not be received on behalf of another player. The player would be entitled to "payment" in the form of the loot drop the moment the quest or raid had been completed.

In Commissioner for South African Revenue Service v Brummeria Renaissance (Pty) Ltd and others (2007) (69 SATC 205), the Supreme Court of Appeal held that the "benefit" derived from using an interest-free loan represented an "amount" and had to be included in gross income. If, therefore, the taxpayer argued that the loot drops were not taxable, the Commissioner could argue that the loot drop had provided the player with a benefit, that is, to advance to another level or whatever the advantages associated with the loot received might be. This would result in the benefit being seen as an amount that should be included in the taxpayer's gross income.

The last resort for exception is "imputed" income (Camp, 2007: 38-42). Income qualifies as imputed income when a taxpayer receives a benefit arising from personal exertions by the taxpayer on his own behalf. There are two types of imputed income, income from services and income from property. Imputed income from services means that every person performs services for their own benefit. These services have an economic value that would not be included in a taxpayer's gross income. Imputed income from property means that a value could be assigned to the use of assets for a taxpayer's own benefit. The same rule applies to imputed income from services. The imputed income from property has a value but it would not be included in a taxpayer's gross income.

According to Camp (2007:56), a taxpayer's best chance of exception of the loot drop from gross income is the concept of imputed income. The game activities bring a taxpayer in-kind services, playing the game, the enjoyment of self-owned property, and the right to play. Playing a game is compared to a gambling situation when a player wants to get as much "play" as possible for the original cash used to buy casino chips. Only the final amount cashed out by the taxpayer qualifies as gross income.

However, Lederman's research does not agree with the basis of Camp's research. Lederman (2007:16441646) is of the opinion that loot drops are not owing only to the actions of the taxpayer; but that a third party, the game owner, is also required to receive the virtual items. The fact that a loot drop might be their property increases its chances of being seen as an award or prize. Lottery winnings and game show prizes all qualify as gross income and are therefore taxable in the US. If the loot is not considered property (for the purposes of this study it is not), it should be considered part of the game service in return for the monthly game fee.

Lederman (2007:1644-1648) uses principles laid down by Professor Joseph Dodge to explain the tax effect of loot drops. Loot drops require a substantial investment in time and effort on the part of the players. According to Dodge there is no difference between "self-created" objects and "taken" objects. The only difference is the person who has invested in the time to create the object. Virtual property resembles "taken" property, because it requires substantial effort on the part of the taxpayer, but it is not self-created by the taxpayer, who depends on the effort of the game's designers to create the items. It is only investment by the taxpayer that brings about the loot drop. However, it would become taxable only once the taxpayer had sold the loot. A loot drop would therefore not be taxed until the player had entered into a transaction to cash out the value of the loot drop.

Hamel et al. (2008:30) explain the concept of "imputed" income in the South African context as hypothetical income, income that could have been earned if an amount had been invested. This kind of hypothetical interest would not be included in gross income. No other South African publication could be found explaining exactly when income would not qualify as hypothetical interest. But Lederman's dissenting argument makes sense. Normally, hypothetical income does not involve any third party. The fact that a taxpayer uses an asset and therefore cannot earn income from it does not involve a third party. When a taxpayer delivers a self-service instead of using 
the time and skill to earn income, no third party is involved. With a loot drop, the player uses his own skills to follow a "hero's journey" by completing quests, taking part in raids and defeating monsters. Ultimately a third party rewards the player for the use of those skills. Even though the player might be involved in a structured world for entertainment, the loot would have a fairly ascertainable value from the moment it was in the player's hands, and should the player ever decide that he needed the income, it would be readily available.

Camp's comparison of loot drops with gambling winnings might be the saving grace for players. Not only would it save some of them from paying taxes on the loot drops, but it might also go as far as rescuing them from having to pay taxes at all on income earned in structured virtual worlds. But each case would have to be decided on its own merits (De Koker, 2008: \$3.26). If a taxpayer were to use gambling as a form of entertainment, it would be seen as income of a capital nature and would not be included in his taxable income. However, as soon as the gambling activities became systematic and could be seen as a business or a profit-making scheme, the income would be of a revenue nature and would be included in a taxpayer's gross income (Jordaan et al., 2008:27).

In Morrison v CIR (1950 $2 S A 449)$ (A) (16 SATC 377), the following differences between a systematic or professional punter and the occasional better were identified:

But where an ordinary punter simply lays a bet, or bets habitually, this conduct is so irrational from a business point of view that its gains cannot ordinarily be subject to payment of income tax. The reason for this difference is apparently that where persons associated with racing take to betting on the results of races, they have specialised knowledge and sources of particular information which make their occupation less irrational by reducing substantially the purely arbitrary results of their efforts. Where the element of risk and arbitrary gain or loss is reduced substantially the betting on horse races becomes, not irrational, but an undoubted means of making income. If it remains entirely irrational there is a good deal to be said for the view that its gains can hardly be made the subject of income tax any more than its losses can be deducted from normal income.

Even though it depends on the facts of each individual case, it is all about how regularly a taxpayer takes part in gaming activities. According to SARS' practice, gambling winnings are taxed when transactions take place on a systematic basis. Not even ordinary punters will get taxed on gambling winnings if they take part for entertainment purposes (De Koker, 2008:\$3.26).

Lederman's argument against Camp's 'imputed income' is the 'self-created' object by Dodge. If the actions around a loot drop were investigated, it is doubtful whether Lederman's argument could prevent income from qualifying as gross income under South African income tax legislation. A player would have to invest a significant amount of time in forming a guild and completing a quest or raid. Should the player be successful, the game owner would decide what prize to award him. Lederman's argument against 'imputed income' was that a third party was involved in the transaction. However, the same would be true of the 'self-created' argument. In return for the time and effort invested by the player, a loot drop with a fairly ascertainable value would be awarded. Even though this does not resemble a straightforward service delivered for a fee, this principle concurs with the benefit received in Commissioner for South African Revenue Service $v$ Brummeria Renaissance (Pty) Ltd and others (2007 69 SATC 205). On the other hand, a taxpayer could argue that the monthly service charged was payment for the benefit and that the loot had been received in the same way in which inventory is bought and received. In this instance, inventory would not be included in the taxpayer's gross income until he sold the inventory.

The only relief for the South African taxpayer appears to be the ability to prove that the transactions would be of a capital nature and that participation was purely for entertainment, with no intention of profit-making.

\section{In-world Transactions}

According to Lederman (2007:1653), there is a strong argument that in-world exchanges would not qualify as gross income if a player only had a license for using items in the game world. If two taxpayers exchanged the use of an item, no physical disposal would have taken place, as the items would not be owned by the taxpayers. If two players exchanged items in-world, it could be argued that the only transaction to have taken place was a relocation of the items within the domain controlled by the game-owner. If the exchange was accompanied by a real-world 
payment, this would constitute gross income, but the exchange of the right to use a certain item would not be treated as a realisation and would therefore not qualify as gross income.

Even though Lederman tries to argue the possibility that a player would only have a license to use items in the game world, by now we know that players trade with their in-world items in real money, even though, in accordance with several of the structured world EULA and TOS agreements, they are not allowed to do so. This confirms the real-money value of the virtual items "owned" by players. The rules for real-world exchanges would therefore apply to in-world exchanges. As explained with reference to loot drops, the gross income definition includes the total amount received in cash or otherwise. This means that a taxpayer would have to include in their gross income the value, otherwise than in cash, of any assets received. Where one asset is exchanged for another, the value of the asset received by the taxpayer, not the value of the old asset, would be included in gross income (Jordaan et al., 2008:13). Therefore, if a player was to exchange a magic cloak for a powerful sword in a structured world, the value to be included in the taxpayer's gross income would be the fair market value of the sword.

When a real money exchange accompanies the in-world exchange, the true intention of the parties must be considered (Clegg \& Stretch, 2008:\$4.10). In Lace Proprietary Mines Ltd v CIR (AD 1938) (9 SATC 349), it was stated that the true intention of the two parties was to exchange mining rights for shares, but the sale included a cash amount. The court held that the intention was the exchange of the assets and the money paid was not intended to be the real purchase price of the transaction. Every in-world transaction would therefore have to be judged on its own merit to determine the player's true intention. However, the transaction would not be treated as two separate sales transactions. Both the in-world and the real world exchanges would be taken into account to determine the net gross income from the transaction.

Camp $(2007: 46-56,65)$ follows the same arguments on in-world transactions as for the loot-drops. His ultimately concludes that no money flows in a virtual world when transactions are taking place, and that both the prizes and the in-world exchanges are merely play. Play means that no real money flows, only representations of real money, "units of play".

The same South African tax principles as applied to Lederman's opinion apply to Camp's argument. Each individual transaction would determine whether the exchange was of a revenue or capital nature, which would indicate whether any amount would be included in gross income. If the transactions taking place were merely "play", the exchanges would be classified as being of a capital nature and would therefore not be included in gross income. However, if the player was engaged in a profit-making scheme and "systematic" and regular trade was taking place, there would be a good chance of the amounts being included in gross income.

\section{Real Money Transactions}

All completed research agrees that real money trade or real money transactions give real economic value to virtual worlds, and are the reason why income from virtual worlds would attract the attention of tax authorities. It is reported that one of the third-party auction sites estimated that $\$ 880$ million of virtual item trade were recorded on the site (Salyer, 2005). Even though certain EULAs and TOS agreements ban the sale of virtual items, this can be limited in-world only to a certain context, as trading goods is an essential aspect of game play.

According to Camp (2007:44), if a player in a structured virtual world were to sell any virtual item or the players were to account for real money, the income from the sale would qualify as gross income, regardless of all the differences in opinion about virtual property and where ownership lies. If players had no property rights in virtual items, transactions would be classified as the sale of services, as one player in the game assists another player either to enhance play or to "level up" a character. If players had property rights in virtual items, transactions would be classified as a sale of property and would be subject to $\$ 1001$ of the Federal Income Tax Code which ultimately constitutes gross income with the basis of the virtual item being allowed as a deduction from the sale amount.

Players might want to defend the taxability of income owing to a EULA or TOS not allowing trade of inworld items. According to $\$ 61$, income received does not have to be "moral, immoral, legal or illegal" to qualify as 
gross income (Camp, 2007:45). Another argument by players is that real money trade simply results in a lesser game cost, but $\$ 61$ does not depend on the intent of the taxpayer. Whatever the income, it would be included in gross income.

Even though the EULAs and TOS agreements in a number of structured worlds ban the trade of virtual items, players still trade the items on a number of well-publicised auction sites. The EULAs and TOS agreements initially giving players limited property rights in their virtual items are not enforced and the contractual restrictions can therefore not be seen as a true refection of players' actual ability to trade and realise virtual items to real world value (Camp, 2007:54). However, the fact that players are illegally trading with their virtual items has no effect on whether an amount would qualify as gross income or not. CIR v Delagoa Bay Cigarette Company Ltd (1918 TPD 391) (32 SATC 47) decided that, even though a business which produced income might not be a legal trade, the income would still be included in gross income. The fact that a transaction is illegal or immoral does not determine whether or not it is gross income. The underlying transaction determines whether income will qualify under the gross income definition (ITC 1789 (2005 67 SATC 205)).

The fact that a player was trading in real money with his virtual items, even though it was banned by a EULA or TOS, would not mean that the transaction could not qualify as gross income. If the underlying transactions resulted in income-producing activities, the gross income definition might be applicable and the income could be included in a taxpayer's taxable income.

\section{CONCLUSION ON INCOME FROM STRUCTURED VIRTUAL WORLDS}

Even though it is generally thought that income received from a structured or game world would not be taxable because it was merely a game, the research indicated that this might not necessarily be the case if South African tax legislation were to be applied.

As far as loot drops are concerned, previous research did not agree on whether they should be taxable, but the studies concurred that loot drops should not be taxed unless a cash-out transaction took place. According to South African income tax legislation, loot drops appear to qualify as gross income, as they qualify as an "amount received or accrued in cash or otherwise", as required by the definition.

The conclusion in previous research was that in-world transactions should not be taxable until a cash-out transaction had taken place. South African income tax principles appear not to concur with the US principles. As for loot drops, in-world transactions qualify as gross income according to the definition in the South African Income Tax Act. Real-money transactions are the only type of transaction in which both the US and the South African income tax perspectives include any form of transaction involving real-money trade in gross income.

\section{INCOME EARNED FROM UNSTRUCTURED VIRTUAL WORLDS}

For the purposes of this study, unstructured worlds/virtual worlds are defined as “... environments where the owners of the worlds provide a basic environment and users create most of the in-world content. Examples of such unstructured worlds are Second Life, the Sims Online and There" (Lederman, 2007). The greatest overall difference between structured and unstructured virtual worlds would probably be the fact that unstructured worlds like Second Life are not considered games. The impact of this view could be substantial when the "receipts and accruals of a capital nature" principles are considered. The most important test for determining whether income is of a capital or revenue nature is the test of intention (Jordaan et al., 2008:21).

Case law exists relating to horse racing and whether or not it would constitute a hobby or a business (ITC $712(195017$ SATC 335(N))). It has also been the subject of several articles over the years (Williams, 1996:50). The general conclusion is that the advantage of treating an activity as a hobby would be that the taxpayer would not be taxed on any income flowing from the activity. It should, however, be borne in mind that if a taxpayer's hobby was on such a scale that it took the form of a business, it would be argued that it was indeed a business, not a hobby. The tax treatment of a hobby seen as a business would be the same as that for a normal business; income would be considered as being of a revenue nature and would therefore be included in the taxpayer's gross income. 
Should unstructured virtual worlds not be seen as games, the question arises as to why someone would become a resident of a virtual world if not to play a game, especially given that the owners of an unstructured virtual world like Second Life encourage their residents to trade. As far as the hobby versus business argument is concerned, income from virtual unstructured worlds might be considered income from a business and would therefore be included in the taxpayer's gross income. With the possible argument that all transactions in unstructured worlds could be considered as being for business purposes, the following section explains more about the working of unstructured virtual worlds and why they are attracting the attention of tax authorities.

\section{UNDERSTANDING UNSTRUCTURED VIRTUAL WORLDS}

Real economies are emerging within digital online fantasy worlds. The largest virtual worlds such as Second Life, collectively hosts millions of citizens, some spending many hours every day living their virtual lives. Virtual fantasy worlds have become a serious business in their own right. There is a steady blurring of the line between fantasy and reality, which is leading real people to spend real money on entirely virtual goods and services (Deloitte: 2007).

Is this all merely play? Or is it what Dan Miller was referring to when he said, "The more it seems to be parallel to the real world, the easier it will be to introduce taxes to it" (Datastream, 2007:11). Linden Lab, the creator of Second Life, does not consider it a game at all, describing it as an unstructured online universe (Stamper, 2007). This opinion is also supported by the auction site eBay, which specifically distinguishes between virtual games and Second Life (Terdiman, 2007). However possible it might be to build games within the Second Life environment, this still does not make Second Life a game (Svarog, 2006). Players instead use it for socialising and taking part in everyday activities. As in structured worlds, players also use an avatar that assumes a role within the context of the unstructured virtual world (Camp, 2007: 5).

Given that co-operation is an important aspect of game play in structured virtual worlds, player interaction is crucial to a successful life in an unstructured virtual world like Second Life. The interaction can be social, cooperative or competitive. Ultimately, most interaction requires players to trade in order to increase the fun of their experience of living in this virtual world (Camp, 2007:6). As with structured virtual worlds, trade is the driver of the in-world economy and explains the increasing interest of tax authorities.

\section{REASON FOR TRADE IN UNSTRUCTURED VIRTUAL WORLD ASSETS}

Whereas the trade of virtual items from structured virtual worlds is banned by some virtual world designers and auction sites, items in Second Life are specifically exempt from this ban (Terdiman, 2007). Second Life is described as:

"...an online, $3 D$ virtual world imagined and created by its residents. ...Because residents retain intellectual property rights in their digital creations, they can buy, sell and trade with other residents."

It thus appears that, other than entertaining its owners, the main purpose of this unstructured world is the promotion of trade amongst its residents, which the creators explain as the interaction of "the World", "the Creations" and "the Marketplace" (Second Life, 2008). Second Life is not the only unstructured world in which trade is encouraged. The virtual items used in Entropia Universe deteriorate on a regular basis and players have to pay real world currency to replace them. This encourages continuous trade within this unstructured world (Mindark, 2008). Second Life's TOS agreements with residents further support trade by specifically stating that residents can retain any intellectual property in their own creations (Second Life, 2008). According to Lederman (2007, 1630), awarding intellectual property rights to residents encourages creativity and "entrepreneurial activity".

In-world trade thus plays a very important role within unstructured worlds. Second Life has even been described as a 3D world devoted to capitalism (Konrad, 2006). Camp (2007:10) emphasises that unstructured worlds have to promote player-to-player transactions to retain residents' interest, as there are no "heroes' journeys" as there are in structured worlds. This trade could be in the form of an in-world item exchanged for another in-world item, but more often than not residents sell their in-world creations for an amount in Linden dollars, Second Life's currency. 


\section{DOES TRADE IN STRUCTURED VIRTUAL WORLDS RESULT IN REAL MONEY TRADE?}

As in structured worlds, residents of an unstructured world like Second Life have to pay a monthly subscription fee (Lederman, 2007:1622). There is free basic membership, but to be an active trading resident and own land in Second Life, there is a monthly subscription fee (Second Life: 2008). These membership plans entitle the resident to an occasional allowance, but, as in structured virtual worlds, a resident can put more real money into the virtual world to give the avatar more skills and in-world possessions (Camp, 2007:11). The real money input can mean that more in-world currency is bought to trade in-world, or, alternatively, real-money can be used to buy virtual items from internet auction sites. Also, as in structured virtual worlds, the virtual item has to be handed over in-world, even if the transaction took place in real-world currency.

There are many apparent similarities between structured and unstructured virtual worlds, but from the US perspective the differences in tax treatment are marked. The debates on both unstructured and structured virtual worlds are concerned with whether tax would be payable on both in-world and real-world transactions.

\section{A CRITICAL ANALYSIS FROM THE SOUTH AFRICAN PERSPECTIVE}

This section considers completed research regarding the taxation of income earned in unstructured virtual worlds. These studies were carried out based on gross income as defined in $\$ 61$ of the Federal Income Tax Code of the USA. Section 1 of the Federal Income Tax Code of the US imposes income tax on taxable income which equates to gross income minus deductions as per $\S 63$. Gross income is defined by $\S 61$ as "all income from whatever source derived". According to US case law, income means "any undeniable accessions to wealth clearly realised and over which the taxpayer has complete dominion". Clearly it is not the form of income but access to it that is important.

The outcomes of the completed studies are compared in terms of this information and a critical analysis from the South African perspective.

\section{In-world Transactions}

Unlike a structured world, an unstructured world like Second Life does not take loot drops into account (Lederman, 2007:1669). The in-world transactions are limited to trade amongst residents, and comprise virtual item for virtual item (including virtual services) or virtual item for in-world currency.

As far as structured worlds are concerned, previous studies concluded that in-world transactions should not be taxed, unless they involved a cash-out transaction (Lederman, 2007:1624). But the complexity of transactions increases if the rights of residents of Second Life are taken into account. Because residents retain the intellectual property rights to their creations (Second Life, 2008), they are allowed both to sell their original creations and to make and sell copies of them (Lederman, 2007: 1655). This right enables residents to involve themselves in trade to a far greater extent than the players in a structured world would ever be able to do.

Whereas income earned by players in structured virtual worlds would possibly be seen by revenue services as a prize or award, trade within Second Life might resemble a barter club. According to Camp (2007:32), bartering is as much a realisation event as a cash transaction would be, so a taxpayer would be duty bound to report such transactions.

As the US gross income definition has such a broad reach, the only possible exclusions from the definition would be the tested "priceless", "unrealised" and "imputed" income exceptions. Income earned from an in-world sale, in which a virtual item is exchanged for the in-world currency, Linden dollars, has a very small claim to qualify as a "priceless" exception. Exchange between US dollars and Linden dollars is freely available in-world, and Linden Labs also runs an in-world auction site that enables residents to trade freely with any virtual items. As an in-world transaction would easily be converted to a readily-ascertainable fair market value, income from unstructured virtual worlds would not qualify as a priceless exception. 
According to South African income tax legislation, income from any barter or exchange transaction should be included in a taxpayer's gross income. The definition of gross income in South Africa includes any form of property received or accrued to the taxpayer (De Koker, 2007: \$2.16). An income has to be "an amount received or accrued" for gross income to be recognised (Hamel et al., 2008: 29). When a virtual item is sold to another resident in-world for in-world currency, the in-world currency can be converted to US dollars and then to South African rands. As income from unstructured virtual worlds has a readily ascertainable fair market value, it would qualify as income according to the definition of gross income in the South African Income Tax Act.

When it was stated that loot drops are not a realisation of wealth as no actual cash, property or service has been received by the taxpayer (Camp, 2007:47), the argument was that the fewer rights a taxpayer had in a virtual item, the better the chances that the income would qualify for the exception. This means that because the Second Life EULA and TOS agreement awards all the intellectual property rights to their residents, a resident has the right to sell, separately, both the design of a certain virtual item and the right to copy it. (Camp, 2007:56) According to Camp (2007:56), taxpayers' argument that their "ability to convert the loot to usable wealth is remote and dependant on factors beyond" would not hold. To argue that the game owner might flood the market with Linden dollars, causing rampant inflation, is much the same as saying that the real world factors are beyond a taxpayer's control. Income from unstructured virtual worlds would therefore not qualify for the realisation exception.

The "realisation" exception is similar to the "received by or accrued to" element of the South African gross income definition (section 1 of the South African Income Tax Act). A resident's in-world account is credited with the sales amount in in-world currency as soon as the sale has taken place. The in-world currency can then be used for the resident's benefit. As in a real-world sale, a resident is entitled to in-world currency the moment the sales transaction is concluded and the in-world item is then transferred to another resident.

Similar to his argument on loot drops, Camp's (2007:61-64) research discusses at great length the reasons why income from unstructured virtual worlds, and specifically Second Life, should be considered "imputed" income and should therefore not be taxable. He explains that residents have far fewer rights over their creations than they imagine. The claim is that an in-world item has to be unique if a resident is to be entitled to property copyright. Camp, however, claims that the copyright would be worthless if Second Life no longer existed.

The concurrent argument is that residents have even fewer rights in Linden dollars. Camp explains that these merely look and act like currency. It is even claimed that a resident might have fewer rights in Linden dollars than in casino chips. Ultimately, the limited license right to use Linden dollars is classified in the same way as for units of play. This implies that the income is "imputed" income, confirming Camp's statement that in-world transactions should not be taxed unless a cash-out transaction has taken place. Until real-world businesses accept Linden dollars as payment for real-world items, in-world transactions will be safe from tax (Camp, 2007:64).

It is considered highly unlikely that the income from an unstructured world like Second Life would be considered imputed income under South African income tax legislation. The fact that a taxpayer is a resident of Second Life and has entered into some kind of transaction explains any income earned from these unstructured virtual worlds. There seems to be no resemblance to what Hamel et al. (2008:30) describe as imputed income as far as South African income tax is concerned. Imputed income is what a tax payer would earn should he enter into a certain transaction. With income from unstructured virtual worlds, the taxpayer would already have entered into a transaction that had monetary value, so the exemption would definitely not be available to a South African taxpayer.

In contrast, Lederman's (2007: 1620) research states that income earned in co-modified virtual worlds like Second Life should be taxed, regardless of whether residents ever cashed out their in-world profits.

The same tax consequences appear to apply in South Africa to a resident earning income from trade in Second Life. The South African definition of gross income includes all amounts "in cash or otherwise" (section 1 of the South African Income Tax Act). This means that, if a taxpayer earned income in a form other than cash, that income would still be included in their gross income. With the exchange of a virtual item for Linden dollars, the rate of exchange to dollars would be used to convert the value of the income to real money and the US dollar amount would be converted to South African rand. 
Lederman (2007:1656) emphasises the issue of property rights in Second Life in much the same way as Camp does. If the courts were to find that residents did not own the property rights in in-world creations, a transaction would be no more trading one limited licence item in a game world for another. On the other hand, if a court were to grant Second Life residents ownership rights over copies of their in-world items, these transactions would fall within the US gross income definition. Lederman (2007: 1656-1657) also addresses the limited rights of residents over Linden dollars. According to US legislation, a license to use property may not constitute property for income tax purposes. It appears, however, that should residents obtain rights over property, exchanging it for Linden dollars, which do not constitute property, the transaction would still qualify as a realisation event for tax purposes. If a resident held limited rights over their virtual items, which they exchanged for Linden dollars, this might not be taxable, seeing that the right over the virtual item might not constitute property.

As explained above, if a taxpayer had traded with a virtual item without owning the full property rights, it would not affect the inclusion in gross income of the income earned from the transaction (CIR v Delagoa Bay Cigarette Company Ltd (1918 TPD 291) (32 SATC 47)). In terms of South African income tax legislation the transaction would therefore be taxed regardless of whether the resident was the owner of all the property and copyrights or not.

The exchange of in-world items without the use of Linden dollars or cash is also discussed. Lederman (2007: 1665) is of the opinion that these exchanges should not be taxed, as individual exchanges in Second Life would typically take place only for entertainment purposes. However, if Linden dollars were used to settle a transaction, it would be more difficult to determine whether the transaction constituted only entertainment or whether it was trade as a business. Lederman suggests that trade for in-world currency in Second Life should be taxable. In the case of entertainment, deductions are allowed up to the income included for any hobby. Should the taxpayer be conducting a business within Second Life, this income would still be included in the individual's taxable income.

Under South African income tax legislation, transactions into which a resident entered for purposes of entertainment might qualify as "income of a capital nature" (section 1 of the South African Income Tax Act) and would therefore not be included in his gross income. However, all transactions would have to be assessed on their own merit, and a general exclusion from gross income could not be guaranteed for transactions of this nature.

\section{Real Money Transactions}

According to US legislation, sales of any real world property or services in Second Life would be taxable exactly as they would on an auction site like eBay (Lederman, 2007:1655). Camp (2007: 44) concurs, regardless of what the courts may decide on the property rights in Second Life. A real money sale would be included in gross income just as in the in real world.

The income would be included in gross income even if a taxpayer's intention had not been to make money from the transaction (Camp, 2007: 45). According to Treasury Regulation 1.16-14, a taxpayer's intention does not determine whether or not income from a certain transaction will be included in gross income. When a taxpayer enters into a transaction without the intention of earning income but the outcome is, in fact, income in the taxpayer's hand, it must be reported, even though it had not been the taxpayer's intention.

Residents of unstructured virtual worlds do not have the option of defending the taxability of income from these worlds because trading their virtual items is not allowed (Camp, 2007:45). Linden Lab, the owner of Second Life, encourages trade, whether in-world or in real-money terms. Even if residents could defend themselves by claiming that their trade with virtual items was illegal, the income would still be included in gross income in terms of South African income tax case law (ITC 1789 (2005 67 SATC 205)).

As with the real money transactions in structured virtual worlds, all income earned from real money trade in virtual items from unstructured virtual worlds would be included in the gross income. This type of sale would not differ in any way from a normal real-world transaction generating income, which would be included in gross income in terms of the South African Income Tax Act. 


\section{CONCLUSION ON INCOME FROM STRUCTURED VIRTUAL WORLDS}

The study found that the greatest difference between structured and unstructured virtual worlds is that unstructured virtual worlds are not considered games. Residents of one of the largest unstructured virtual worlds, Second Life, are encourage by its creator, Linden Lab, to trade, whether this be to enhance their in-world experience or to carry out business transactions. The motivation is therefore not only to entertain the residents but also to provide trade and ultimately business opportunities for them.

The South African tax consequences for income earned in unstructured virtual worlds resonate to a considerable extent with the findings of Lederman's research based on US legislation. Whether a transaction had taken place in-world and the in-world income was never cashed out, or whether the virtual item was sold for real money, both transactions would result in the inclusion of the income generated in gross income, as laid down in section 1 of the South African Income Tax Act.

However, should a taxpayer become a resident of one of the unstructured virtual worlds, and traded only for personal entertainment, any income might be of a capital nature and, as set out in the South African gross income definition in section 1, would not be included in gross income. Every transaction would be evaluated on its own merit, especially because the nature of unstructured worlds tends to favour trade rather than play.

\section{LIMITATIONS TO THE STUDY AND SUGGESTIONS FOR FURTHER RESEARCH}

The study was limited to determining whether the income earned by South African residents who are taxed on their world-wide income would be included in gross income as defined by the South African Income Tax Act. Capital gains tax consequences were not considered for any transaction for which the income was classified as being of a capital nature. The study did not consider which deductions might be available to taxpayers in terms of the income being included in gross income and there was no detailed discussion to determine when a taxpayer would be considered as engaging in virtual worlds as a hobby as opposed to a business.

No international tax rules or double taxation agreements were taken into account in determining the tax consequences of the income earned from virtual worlds.

Other researchers could extend the findings of this research to distinguish between participation in virtual worlds as a hobby and the point at which such participation would qualify as a business. The tax consequences of this difference in classification could be investigated.

\section{SUMMARY AND CONCLUSION}

Space was once the 'final frontier'; today the newest worlds exist in cyberspace" (Lederman, 2007: 1620). What seems to have been pure entertainment in the past, now seems to have serious consequences for taxation.

The present study identified the possibility that South African residents would be taxed on their structured virtual world profits unless it could be proved that taxpayers were merely taking part in a game and participating in trade for entertainment purposes. Transactions could be taking place in-world or with real money. In both instances, the income earned would be included in taxpayers' gross income.

This study and previous international research concur that income from unstructured virtual worlds should be included in gross income. There is some debate around the ownership of property and copyright, but, from the South African perspective, even with these uncertainties, in-world income from unstructured virtual worlds appears still to be taxable. Current and previous research agrees that any real money transaction resulting from the in-world trade should be included in a taxpayer's gross income.

Even though taxpayers might think it unreasonable to tax virtual income, the possible consequences of not doing so will grow and drive tax evasion. Significant investment has already been made in Second Life (Lederman, 2007: 1667). Should revenue services world-wide allow tax-free trading to take place in virtual worlds, businesses would soon realise that they could accept in-world currency, and in this way evade the taxman. 
This study agrees that when the gross income definition was initially drawn up, becoming a resident of a virtual world was more unlikely than a trip to space. However, the principles laid down in South African tax legislation will be as effective for the transactions created by the latest technological developments as they would have been for a normal bread and milk sales transaction at the time the legislation was initially drawn up.

\section{AUTHOR INFORMATION}

Saré Pienaar is a Chartered Accountant with a Masters degree in Taxation. She did her trainee accountant contract at the firm of Deloitte. She is a senior lecturer at the University of Pretoria and has lecture experience on graduate and post-graduate level. She has a specific interest in the taxation of internet transactions and transactions occurring in virtual worlds.

Theuns Steyn is a Chartered Accountant with a Masters degree in Taxation. He did his learnership at the firm of KPMG and was also a Senior Audit Manager at Ernest \& Young. He joined the University of Pretoria five years ago and since then he was the programme leader for the MCom Taxation students and also lectured for students on the BCom Hons Taxation degree. Theuns is responsible for assisting both Masters and Honours students with the research part of their specific programmes.

\section{REFERENCES}

1. Arrison, S. 2007. Second Life Tax Man. [Online] Available from: http://www.technewsworlds.com/story/55120.html [Accessed: 2007-03-23]

2. Au, W.J. 2008. What is Second Life? In: Knibbe, W., English, C. \& Cunningham, P. (eds.) Second life: the official guide. Indianapolis: Wiley Publishing.

3. Bartle, R.A. 2004. Virtual worldliness: What the imaginary asks of the real. New York Law School Law Review, 49:19-44.

4. Bray, D.A. 2007. Virtual worlds: multi-disciplinary research opportunities. Advances in Information Systems, 38(4):17-25 [Online] Available from: http://0portal.acm.org.innopac.up.ac.za/citation.cfm?id=1314234.1314239 [Accessed: 2008-02-25]

5. Camp, B.T. 2007. The play's the thing: a theory of taxing virtual worlds. Hastings Law Journal, 59(1):1-66 [Online] Available from: http://works.bepress.com/bryan camp/1/ [Accessed: 2008-02-25].

6. Clegg, D.J.M. \& Stretch, R.W. 2008. Income tax in South Africa. Electronic resource ed. Durban: LexisNexis.

7. Datastream. 2007. Virtual worlds could be taxed. Datastream, March 2007:10-11

8. Deloitte. 2007. Deloitte releases media trends for 2007. [Online] Available from: http://www.bizcommunity.com/Articles/416/15.html [Accessed: 2007-03-27].

9. De Koker, A. 2008. Silke on South African income tax. Electronic resource ed. Durban: LexisNexis.

10. Friedman, M. 2008. Milton Friedman quotes. Not dated. [Online] Available from: http://www.woopidoo.com/business_quotes/authors/milton-friedman-quotes.htm [Accessed: 2008-10-31].

11. Gordhan, P. 2000. E-commerce a "playground" for tax evasion. [Online] Available from: http://www.iol.co.za/general/news/newsprint.php?art_id =qw974730540221B225\&sf=[Accessed: 2008-1106].

12. Guardian.co.uk Games Blog. 2007. eBay bans sale of virtual game goods. [Online] Available from:http://www.guardian.co.uk/technology/gamesblog/2007/jan/31/ebaybanssale [Accessed: 2008-10-20].

13. Jordaan, K., Koekemoer, A., Stiglingh, M., Van Schalkwyk, L., Wasserman, M. \& Wilcocks, J. 2008. Silke: South African income tax. Durban: LexisNexis.

14. Hamel, E.H., Stiglingh, M. \& Venter, J.M.P. 2008. A student approach to income tax Natural Persons. Durban: LexisNexis.

15. Konrad, R. 2006. IBM to open islands in virtual world. [Online] Available from: http://www.washingtonpost.com/wp-dyn/content/article/2006/12/12/AR2006121201905.html [Accessed: 2008-12-03]. 
16. Lymer, A. 2003. Taxation in an electronic world. In: Lamb, M., Lymer, A., Freedman, J. \& James, S. Taxation: an interdisciplinary approach to research, [Online] Available from: http://books.google.com/books?hl=en\&lr=\&id=RkM3UevilikC\&oi=fnd\&pg=PA249\&dq=virtual +taxation \&ots=6-6qRz4pVE\&sig=0zVtEpshwgFjycb5n5Pxs0Syvhw [Accessed: 2008-10-31]

17. Lang, G. 2007. Second Life resident statistics. [Online] Available from: http://secondliferesearch.blogspot.com/2007/03/second-life-residents-statistics.html [Downloaded: 200811-14].

18. Linden Lab. 2008. Second Life virtual economy key metrics. [Online] Available from: http://static.secondlife.com/economy/stats_200808.xls [Downloaded: 2008-11-06].

19. Lederman, L. 2007. 'Stranger than fiction': Taxing virtual worlds. New York University Law Review, 82(6):1620-1672. [Online] Available from: http://0www.law.nyu.edu.innopac.up.ac.za/journals/lawreview//issues/vol82/no6/NYU602.pdf [Accessed: 200802-25].

20. Mindark. 2008. Entropia Universe:The first virtual universe with a real cash economy. [Online] Available from: http://www.mindark.com/entropia-universe/ [Accessed: 2008-12-03].

21. Pasick, A. 2006. Virtual economies attract real-world tax attention. [Online] Available from: http://www.ioltechnology.co.za/article page.php?iSectionId=2887\&iArticleId=3490653 [Accessed: 200703-23].

22. Salyer, S. 2005. The game is virtual. The profit is real. Statement of the president of Internet Gaming Entertainment, Steve Salyer at the second State of Play conference in December 2004. [Online] Available from:

http://www.nytimes.com/2005/05/29/business/yourmoney/29game.html?pagewanted $=2 \& \quad r=1 \&$ sq $=$ the $\% 20$ game\%20is\%20virtual\&st=cse\&scp=1 [Accessed: 2008-11-28].

23. Second Life. 2008. Membership plans. [Online] Available from: http://secondlife.com/whatis/plans.php [Accessed: 2008-12-03].

24. Second Life. 2008. Terms of service. [Online] Available from: http://secondlife.com/corporate/tos.php [Accessed: 2008-12-03].

25. Second Life. 2008. What is Second Life? [Online] Available from: http://secondlife.com/whatis/[Accessed: 2008-12-03].

26. Stamper, D. 2007. Taxing ones and zeros: Can the IRS ignore virtual economies? [Online] Available from: http://www.taxanalysts.com/www/features.nsf/Articles/23B6E6BBD4CEBBC38525727300691993?Open Document [Accessed: 2008-12-03].

27. Svarog, F. 2006. Understanding SL: Two takes. [Blog:] Posted by Forseti Svarog on 2006-06-12. [Online] Available from: http://secondslog.blogspot.com/2006/06/understanding-sl-two-takes.html [Accessed: 200812-03].

28. Terdiman, D. 2007. eBay to exempt 'Second Life' listings from virtual items ban. [Online] Available from: http://news.cnet.com/8301-10784 3-6154277-7.html?tag=mncol [Accessed: 2008-12-03].

29. Williams, G. 1996. Horse-racing: Business or pleasure? Tax planning, 10:50-53.

30. Woodcock, B.S. 2008. MMOG Active subscriptions World of Warcraft. Updated on 2008-04-09. [Online] Available from: http://www.mmogchart.com/Chart11.html [Downloaded: 2008-11-14].

31. Woodcock, B.S. 2008. Total MMOG Active subscriptions. Updated on 2008-04-09. [Online] Available from: http://www.mmogchart.com/Chart4.html [Downloaded: 2008-11-14]

32. World of Warcraft. 2008. Introduction to World of Warcraft. [Online] Available from http://www.worldofwarcraft.com/info/beginners [Accessed: 2008-11-25].

\section{LEGISLATION}

Income Tax Act 58 of 1962.

\section{COURT CASES}

CIR v Butcher Bros (Pty) Ltd (1945 AD 301) (13 SATC 21)

CIR v Delagoa Bay Cigarette Company Ltd (1918 TPD 391) (32 SATC 47)

CIR v Delfos (1933 AD 242) (6 SATC 92) 
CIR v People's Stores (Walvis Bay) (Pty) Ltd (1990 (2) SA 353 A) (52 SATC 9)

Commissioner for South African Revenue Service v Brummeria Renaissance (Pty) Ltd and others (2007) (69 SATC 205)

Geldenhuys v CIR (1947 3 SA 256) (C) (14 SATC 419)

ITC 712 (1950 17 SATC 335(N).

ITC 932 (1961 24 SATC 341)

ITC 1789 (2005 67 SATC 205

Lace Proprietary Mines Ltd v CIR (AD 1938) (9 SATC 349)

Morrison v CIR (1950 2 SA 449) (A) (16 SATC 377)

Ochberg v CIR 5 (1931 AD 215) (5 SATC 93)

SARS v Cape Consumers (Pty) Ltd (1999 (4) SA 1213) (61 SATC 91)

WH Lategan v Commissioner for Inland Revenue (1926) CPD 203, SATC 16 